„Analecta Cracoviensia” 51 (2019), s. 161-178

DOI: http://dx.doi.org/10.15633/acr.3638

Lidia Macheta

ORCID: 0000-0002-0895-1383

Uniwersytet Jagielloński

\title{
Miłosierdzie antropologiczne w doświadczeniu mistycznym (Faustyna Kowalska) i refleksji filozoficznej (Józef Tischner). Elementy (teo-)antropologii ontologicznej \\ CZĘŚĆ I
}

Niniejszy artykuł stanowi pierwszą część studium poświęconego zjawisku miłosierdzia antropologicznego, rozpatrywanego od strony człowieka okazującego je wobec innych ${ }^{1}$. Takie rozumienie miłosierdzia można odnaleźć w Dzienniczku² Faustyny Kowalskiej oraz w myśli filozoficznej Józefa Tischnera ${ }^{3}$. Wizja miłosierdzia antropologicznego utrwalona w Dzienniczku Kowalskiej wyodrębnia się jako aspekt sporządzonego przez nią zapisu

\footnotetext{
- W odróżnieniu od miłosierdzia antropologicznego rozpatrywanego od strony człowieka doświadczającego go ze strony innych.

2 W analizach Dzienniczka opieramy się na wydaniu: F. Kowalska, Dzienniczek. Miłosierdzie Boże w duszy mojej, Warszawa 2005; z tego wydania pochodzą wszystkie cytaty z Dzienniczka [dalej jako: Dz. wraz z podaniem bocznej numeracji ustępów]. Na temat charakteru teologicznych treści zawartych w Dzienniczku por. słowa badacza: „Nauka Faustyny jest [...] nauką doświadczenia wiary, a nie doktryny" (I. Werbiński, Idea miłosierdzia jako rys duchowej postawy chrześcijańskiej w ujęciu siostry Faustyny, w: Miłosierdzie w postawie ludzkiej, red. W. Słomka, Lublin 1989, s. 197).

$3 \mathrm{~W}$ artykule interesuje nas wymiar antropologiczny myśli Tischnera.
} 
własnego, zakorzenionego w wierze chrześcijańskiej doświadczenia mistycznego ${ }^{5}$, którego głównym przedmiotem jest miłosierdzie Boże. Koncepcja miłosierdzia antropologicznego zawarta w myśli Tischnera stanowi element jego filozofii osoby ${ }^{6}$, rozwijanej na bazie chrześcijańskiej wizji człowieka ${ }^{7}$. Porównanie obu tych wizji miłosierdzia antropologicznego jest przedmiotem badawczym studium złożonego $\mathrm{z}$ dwóch powiązanych ze sobą artykułów. Analizy umieszczone w pierwszym $\mathrm{z}$ nich, niniejszym, koncentrują się na wizji miłosierdzia antropologicznego ukazanej w Dzienniczku. Są one poprzedzone wstępnymi rozważaniami dotyczącymi całego dwuczęściowego studium. Na rozważania te składa się wstępne zestawienie określonych w tytule wizji miłosierdzia i określenie problemu oraz celu badawczego - wspólnych dla dwóch części studium. Drugi stanowiący o nim odrębny artykuł będzie się skupiał na koncepcji miłosierdzia antropologicznego wyłaniającej się z myśli Tischnera. W uwagach końcowych drugiej części studium zostanie przedstawiona synteza dwóch badanych w nim ujęć miłosierdzia. Zestawmy wstępnie określone w tytule ujęcia miłosierdzia, w pierwszej kolejności biorąc pod uwagę leżącą u ich podstaw wizję człowieka.

W zapisie Kowalskiej człowiek jest istotą religijną (por. Dz. 775). W myśli Tischnera człowiek to byt o dwóch wymiarach: etycznym ${ }^{8}$

4 Zob. J. Machniak, Doświadczenie Boga w Tajemnicy Jego Miłosierdzia u Bł. Siostry Faustyny Kowalskiej. Studium krytyczne w świetle myśli teologicznej, Kraków 1999, s. 12.

5 Na temat doświadczenia mistycznego Kowalskiej zob. J. Machniak, Chcę żyć miłością. Życie mistyczne św. siostry Faustyny Kowalskiej, Kraków 2002, passim; D. Wider, Mistyka sługi Bożej siostry Faustyny, w: Posłannictwo siostry Faustyny, red. C. Drążek, Kraków 1991, s. 79-94. Na temat znaczenia mistyki Kowalskiej zob. słowa badaczki: „Największa oryginalność mistyki siostry Faustyny polega na tym, że po raz pierwszy w historii duchowości Miłosierdzie Boga stanowi centrum mistycznej wiedzy i programu apostolskiego" (L. Grygiel, Zawierzyć Bożemu miłosierdziu. Mistyka siostry Faustyny, Kraków 2000, s. 356).

Por. słowa Tischnera: „Zajmuję się filozofią osoby [...]” (Spotkanie. Z ks. Józefem Tischnerem rozmawia Anna Karoń-Ostrowska, Kraków 2003, s. 132). Jako osobny temat zagadnienie miłosierdzia pojawia się we fragmencie myśli Tischnera bezpośrednio odnoszonej do zapisu Kowalskiej (zob. J. Tischner, Drogi i bezdroża miłosierdzia, Kraków 2015, s. 59-60, 63-64, 74-88 i zwł. s. 119-133). We fragmencie tym idea miłosierdzia antropologicznego otrzymuje od filozofa bardzo zwięzłe ujęcie; dlatego w analizach nie zostanie wydzielona specjalna część dla niego.

7 Na temat chrześcijańskich źródeł Tischnerowskiej filozofii człowieka zob. T. Gadacz, Chrześcijańskie korzenie Tischnerowskiej filozofii człowieka, „Znak” 2004 nr 588, s. 78.

8 Przyjmujemy następujący zapis: tam, gdzie bez dodatkowych określeń występuje słowo „etyka” i słowa pochodne od niego, chodzi o etykę naturalną - różną od etyki religijnej. Pierwsza z nich interesuje nas tylko w zakresie myśli Tischnera, gdzie oznacza etykę czerpiącą z zobowiązania 
i religijnym ${ }^{9}$, to także - istota metafizyczna ${ }^{10}$. W obu porównywanych wizjach człowieczeństwo jawi się jako zadanie do podjęcia. Zestawiane koncepcje miłosierdzia rozpatrywane od strony jego podmiotu ludzkiego dają się wobec tego rozważać na płaszczyźnie antropologii ontologicznej ${ }^{11}$. Bada ona człowieka od strony możliwości i powinności bycia sobą ${ }^{12}$. W Dzienniczku ontologiczny wymiar człowieka ujawnia się w wezwaniu do doskonalenia religijnego ${ }^{13}$ (Dz. 984), polegającego na upodabnianiu się do Boga (Dz. 604). W myśli Tischnera ontologiczny aspekt człowieka ${ }^{14}$ ujmowanego jako byt osobowy odsłania się w wymogu personalizacji ${ }^{15}$ : etycznej $^{16}$, religijnej ${ }^{17}$ oraz metafizycznej. Personalizacja etyczna spełnia się w wydawaniu świadectwa wielkości drugiego człowieka ${ }^{18}$. Personalizacja

moralnego, pochodzącego z „twarzy” drugiego człowieka i bywa wymiennie nazywana „etyką moralności” lub „etyką dialogiczną”. O człowieku jako „istocie etycznej” zob. J. Tischner, Etyka wartości i nadziei, w: D. von Hildebrand, J. Kłoczowski, J. Paściak, J. Tischner, Wobec wartości, Poznań 1984, s. 56.

9 Por. słowa Tischnera: „W duszy każdego człowieka istnieje [...] pragnienie Boga. [...] Pragnienie jest pierwotne, wszystko inne - wtórne” (J. Tischner, Etyka solidarności, Kraków 2005, s. 244).

${ }^{10}$ Zob. J. Tischner, Myślenie w żywiole piękna, Kraków 2005, s. 286.

${ }^{11}$ Dalej wymiennie: onto-antropologia.

${ }_{12}$ Projekt antropologii ontologicznej wypracowujemy zwłaszcza w przygotowywanej rozprawie habilitacyjnej. Elementy tego projektu zostaną niniejszym wprowadzone w maksymalnie wąskim zakresie - stosownie do potrzeb badawczych. W sensie stosowanym w artykule i odnoszonym do antropologii pojęcie „ontologia” bezpośrednio nie pojawia się ani w zapisie Kowalskiej, ani w myśli Tischnera. Zaznaczmy przy okazji, że polski filozof w sposób krytyczny odnosi się do pojęcia "ontologia”, którym posługuje się w - innym od stosowanego przez nas - znaczeniu teorii bytu, opisującej zjawiska specyficznie ludzkie „za pomocą kategorii bytu jako bytu”. Zob. T. Gadacz, Bóg w filozofii Tischnera, „Znak” 2001 nr 550, s. 33.

${ }_{13}$ O miłosierdziu w kontekście dążenia do doskonałości człowieka z zapisu Kowalskiej zob. S. Urbański, Miłosierdzie drogq do świętości według św. Faustyny, „Veritati et caritati” 5 (2015), s. 107.

14 Por. słowa Tischnera: „Dwa te pojęcia: «człowieczeństwo» i «bycie sobą» traktujemy jako równoważne” (J. Tischner, Spór o istnienie człowieka, Kraków 1998, s. 280) - i w tym kontekście: stawanie się sobą to „uczłowieczanie”. Por. J. Tischner, Polski młyn, Kraków 1991, s. 282.

${ }_{15} \mathrm{O}$ aksjologicznym ujęciu personalizacji zob. J. Tischner, Polski..., dz. cyt., s. 54.

${ }^{16}$ Por. słowa Tischnera o człowieku jako istocie etycznej, która „buduje siebie” (J. Tischner, Etyka wartości..., dz. cyt., s. 59). Por. także słowa Tischnera: „Czym jest [...] przeżycie powinności etycznej? [...] ostatecznie nie jest niczym innym, jak ujawniającą się w nas wewnętrzną potrzebą [...] udoskonalenia, potrzebą stania się sobą" (J. Tischner, Jak żyć?..., dz. cyt., s. 10).

${ }_{17}$ Por. słowa Tischnera: „[... ] wiara w chrześcijaństwie nie jest wiarą samą dla siebie, ale po to, by tworzyć człowieka" (J. Tischner, Nadzieja czeka na słowo, Kraków 2011, s. 30).

18 Por. J. Tischner, Krótki przewodnik po życiu, Kraków 2017, s. 30. 
religijna polega, podobnie jak w zapisie Kowalskiej, na upodabnianiu się do $\mathrm{Boga}^{19}$. W personalizacji metafizycznej osoba staje się sobą $\mathrm{w}$ relacji do dobra ${ }^{20}$, określonego przez Dobro absolutne, będące „poza bytem i niebytem" 21 .

Spójrzmy wstępnie na badane wizje miłosierdzia z perspektywy (teo-)antropologii ontologicznej ${ }^{22}$.

W Dzienniczku miłosierdzie antropologiczne pojawia się w sferze etycznej religii (por. Dz. 861). Jako zjawisko etyki religijnej miłosierdzie to w sposób pełny wyraża się w przebaczeniu (Dz. 1148). W nim kulminuje upodabnianie się do Boga (Dz. 1148) - stawanie się sobą człowieka religijnego z zapisu Kowalskiej. Podobnie na gruncie filozofii Tischnera w miłosierdziu antropologicznym kulminuje etyczny wymiar personalizacji religijnej. Również w myśli polskiego filozofa „szczytem”23 tego miłosierdzia jako zjawiska etyki religijnej jest przebaczenie. Inaczej niż w zapisie Kowalskiej, w myśli Tischnera badane miłosierdzie stanowi też optimum personalizacji etycznejej ${ }^{24}$ metafizycznej ${ }^{25}$. Stanowiące o Tischnerowskim miłosierdziu antropologicznym wymiary: etyczny i religijny są określane przez jego aspekt metafizyczny ${ }^{26}$ i wzajemnie na siebie oddziałują w bycie człowieka: etyka warunkuje egzystencjalnie re$\operatorname{ligię}^{27}$; religia stanowi o podstawach ontologicznych etyki - o idei drugiego człowieka ${ }^{28}$.

W ramach wstępnego porównania badanych wizji miłosierdzia przyjrzymy się bliżej sferze ich ogólnego podobieństwa - religii.

19 Por. J. Tischner, Sprawa osoby - wstępne przybliżenie, „Logos i Ethos” 1992 nr 2, s. 7.

${ }^{20}$ Zob. J. Tischner, Filozofia człowieka. Od ontologii do metafizyki człowieka, Kraków 1986, s. 73.

${ }^{21}$ Zob. J. Tischner, Filozofia dramatu, Paris 1990, s. 68.

${ }^{22}$ Nawias nie obowiązuje w odniesieniu do analiz zapisu Kowalskiej.

${ }^{23}$ Zob. J. Tischner, Drogi..., dz. cyt., s. 56-57.

${ }^{24}$ Por. J. Tischner, Zrozumieć własna wiare, Kraków 2006, s.101.

${ }_{25}$ Por. J. Tischner, Myślenie w żywiole..., dz. cyt., s. 290.

${ }^{26}$ Por. T. Gadacz, Filozofia Boga w xx wieku. Od Lavelle’a do Tischnera, Kraków 2007, s. 177.

${ }_{27}$ To znaczy: wartości etyczne są wartościami podstawowymi dla wartości religijnych. Pojęcie „Wartości podstawowych” stosujemy w znaczeniu określonym przez Władysława Stróżewskiego: „Te wartości, których spełnienie warunkuje w sposób konieczny samą możliwość realizacji wartości innych, proponuję nazwać wartościami podstawowymi” (W. Stróżewski, Istnienie i wartość, Kraków 1981, s. 110).

${ }^{28}$ Por. J. Tischner, Etyka wartości..., dz. cyt., s. 145, 146. 
W obu zestawianych wizjach w centrum religii stoi pojęcie łaski Bożej ${ }^{29}$. W obu łaską podstawową jest wolnośćc ${ }^{30}$, a kluczową - miłośćc ${ }^{31}$. Tak w jednej, jak i drugiej wizji „swobodna” (Dz. 201) miłość swój pełny wyraz znajduje $\mathrm{w}$ opartym na wierze religijnej wyborze $\mathrm{Boga}^{32}$. W obu wizjach na aktach religijnej wolności i miłości zasadza się szczególna wartość człowieczeństwa, a religijność jest ufundowana na wewnętrznym doświadczeniu Boga - droga do Boga to poszukiwanie Go we własnym wnętrzu ${ }^{33}$.

W wymiarze religijnym zestawianych wizji miłosierdzia da się także wskazać pewne dzielące je różnice. Na ich podstawie można wstępnie sądzić, że w każdej z tych wizji pojawia się odmienny rodzaj religii łaski. W przypadku wizji z zapisu Kowalskiej byłaby to religia mistyczna, zaś w przypadku Tischnerowskiego ujęcia - religia refleksyjna ${ }^{34}$. Wskażmy teraz ogólne cechy tych dwóch rodzajów religii łaski w obu badanych wizjach.

Wyłaniająca się z zapisu Kowalskiej i ujmowana od strony człowieka religia łaski opiera się na doświadczeniu wewnętrznym, mającym charakter przeżyciowy (Dz. 1560). Specyfika tego doświadczenia zawiera się w odczuciu (Dz. 747) bezpośredniej - „żywej” (Dz. 1410), obecności Boga (Dz. 177) w duszy (Dz. 318), który w niej działa (Dz. 134). Obecność Boga w duszy ludzkiej jest teo-antropologiczną podstawą doskonałości człowieka religijnego z zapisu Kowalskiej (por. Dz. 861). Obecność ta napełnia duszę ludzką doskonalącymi ją łaskami, pochodzącymi z miłosierdzia Bożego (Dz. 1507). Troska o żywą obecność Boga we wnętrzu jako o „skarb niewypowiedziany

29 Por. Dz. 1777; por. J. Tischner, Spór..., dz. cyt., s. 131 - pisząc o religii łaski, Tischner ma na uwadze chrześcijaństwo.

3o Por. Dz. 1331; por. słowa Tischnera: „Do świata wiary wkracza się tylko poprzez bramę wolności” ( J. Tischner, W krainie schorowanej wyobraźni, Kraków 1997, s. 70).

${ }_{31}$ Dz. 450; zob. J. Tischner, $W$ krainie..., dz. cyt., s. 236.

${ }^{2}$ Dz. 373; zob. J. Tischner, Filozofia dramatu..., dz. cyt., s. 32; por. także słowa Tischnera: „Miłość Boga to wybór Boga” (J. Tischner, Alfabet duszy i ciała, Kraków 2018, s. 127).

33 Dz. 454; por. także słowa s. Faustyny: „Nigdy nie szukałam Boga gdzieś daleko, ale we własnym wnętrzu [...]” (Dz. 1302). Zob. słowa Tischnera: „Chrześcijaństwo bardzo wyraźnie mówi: szukaj Boga w sobie. On tam jest!” (A. Michnik, J. Tischner, J. Żakowski, Między Panem a Plebanem, Kraków 1995, s. 556); por. także słowa Tischnera: „Szukamy Boga jako uczestnika naszego (międzyludzkiego - L. M.) dramatu” (J. Tischner, J. Żakowski, Tischner czyta „Katechizm”, Kraków 2009, s. 19).

${ }^{34}$ Sam Tischner religię łaski (chrześcijaństwo) nazywa wymiennie: religią słowa - zob. Przekonać Pana Boga. Z ks. Józefem Tischnerem rozmawiaja Dorota Zańko i Jarosław Gowin, Kraków 2010, s. 45, religią dialogiczną - zob. J. Tischner, Myśli wyszukane, wybór W. Bonowicz, Kraków 2010, S. 20. 
dla duszy” (Dz. 415) wyznacza całość egzystencji człowieka religijnego ukazanego w Dzienniczku. Przy odczuciu tej obecności spełnia się „zażyłe” (Dz. 16) „obcowanie” (Dz. 1302) z Bogiem - aż po „miłosne złączenie” (Dz. 142) z Nim. Stanowi ono o „doskonałości” (Dz. 457) człowieka religijnego z zapisu Kowalskiej. W akcie zjednoczenia miłości Bożej z miłością ludzką, jakie zachodzi w ramach doświadczenia obecności Boga w duszy ludzkiej (Dz. 480), ma miejsce największe odsłonięcie wartości człowieka ukazanego w zapisie Kowalskiej (por. Dz. 1246).

Rozpatrywana od strony człowieka religia łaski ${ }^{35} \mathrm{w}$ rozumieniu Tischnera zasadza się na doświadczeniu wewnętrznym, które ma charakter refleksyjny ${ }^{36}$. Specyfika tego doświadczenia zawiera się w poznawaniu własnej wiary religijnej, nakierowanym na jej zrozumienie ${ }^{37}$ - na „samo-rozumienie człowieka" ${ }^{38}$. Dokonuje się ono poprzez mowę dialogiczną ${ }^{39}$, która jest osadzona na elementarnych doświadczeniach egzystencji ${ }^{40}$. Wierna zasadzie dialogicznej ${ }^{41}$ wiara

${ }^{35}$ J. Tischner, Spór..., dz. cyt., s. 131.

${ }^{36}$ Podstawowy sens tej refleksyjności to identyfikacja własnej wiary. Por. słowa Tischnera: „Wiara nie jest czymś, co przychodzi - ona już jest, tylko my sobie tego nie uświadamiamy. [...] łaska wiary jest nam dana, chodzi tylko o to, by się nam oczy na nią otwarły" (Przekonać Pana Boga..., dz. cyt., s. 30).

${ }^{37} \mathrm{Na}$ temat rozumiejącego wiarę myślenia religijnego jako łasce niosącej prawdę zob. J. Tischner, Myślenie według wartości, Kraków 1982, s. 346. Podkreślając w religii w rozumieniu Tischnera znaczenie wymiaru refleksyjnego, nie twierdzimy, że nie ma go w religii ukazanej w zapisie Kowalskiej. W jego świetle s. Faustyna ceni sobie wartość wszelkiego nabytego rozumienia (własnej) wiary, które odnosi do działań Boga wyrażonych w doświadczeniach życia (Dz. 134); Bogu swego doświadczenia s. Faustyna stawia pytania i oczekuje odpowiedzi (Dz. 134). Jednak religijna dialogiczność Kowalskiej jest podporządkowana nie ideałowi wiary, która domaga się „uznania mocy rozumu” (zob. J Przekonać Pana Boga..., dz. cyt., s. 24), ale wiary mistycznej, pragnącej odczuć bliskość Boga i Jego działanie w duszy (Dz. 134). Wiara taka czerpie wzorzec porozumienia z dialogu Oblubieńców, opartego nie na miłości perswadującej (por. Przekonać Pana Boga..., dz. cyt., s. 9o), lecz na miłości bezsłownej, mistycznej, której, dla wzajemnego zrozumienia, wystarczy „jedno spojrzenie” (Dz. 201).

${ }^{8}$ Zob. Przekonać Pana Boga..., dz. cyt., s. 44.

39 Mowa chrześcijaństwa ma ostateczne trafić do serca, by je „poszerzyć” ( J. Tischner, Alfabet..., dz. cyt., s. 178); por. słowa Tischnera: „Istotą chrześcijaństwa jest [...] sam fakt, że Bóg mówi. W tej perspektywie nie ma innej możliwości budowania religii, jak w oparciu o mowę" (J. Tischner, J. Żakowski, Tischner czyta..., dz. cyt., s. 57).

${ }^{40}$ Zob. J. Tischner, Zrozumieć..., dz. cyt., s. 9.

${ }^{41} \mathrm{O}$ wierze jako odmianie dialogu, który toczy się na poziomie wierności zob. J. Tischner, $W$ krainie..., dz. cyt., s. 235 . 
religijna stawia pytania ${ }^{42}$, które stają się drogą do Boga - drogą „otwartych oczu" ${ }^{43}$. Dzięki tym dialogicznym pytaniom konstytuuje się i ujawnia szczególna godność człowieka ${ }^{44}$. Pytaniom tym przyświeca troska o uniknięcie iluzji religijnej, wiary w bożka ${ }^{45}$ - o wejście na pozycje wiary rzetelnej, odnoszonej do prawdziwego Boga. Sens naczelny dialogicznych pytań wiary to potwierdzenie „wiarygodności pytanego" ${ }^{46}$. Pytająca mowa wiary jest odpowiedzią na Słowo Boga ${ }^{47}$. Jest to „Słowo wybrania"48 dokonanego w "polu miłości”49. Słowo takie rodzi więzi z innym ${ }^{50}$. Dialogicznie pytając, wiara wybiera Innego i potwierdza z Nim więź. Tożsamość wiary dialogicznej zawiera się w wierności dokonanemu wybraniư ${ }^{51}$.

\section{Problem i cel badawczy}

Jakie wnioski można formułować na podstawie roboczego zestawienia badanych wizji miłosierdzia? Wstępnie odsłonięte podobieństwo tych wizji w aspekcie religii pozwala żywić przeświadczenie, że jej mistyczną odmianę z zapisu Kowalskiej łączą z etyką więzi takiego samego wzajemnego oddziaływania, jak w przypadku refleksyjnej wersji religii w rozumieniu Tischnera. Wychodząc od tego przeświadczenia, można badane wizje rozpatrywać z perspektywy jednego problemu: wzajemnego oddziaływania etyki i religii ${ }^{52}$. Problem ten

${ }^{42}$ Por. słowa Tischnera: „Wiara religijna szuka rozumienia, z góry zatem wie, że nic nie wie, w związku z czym pyta drugiego, czeka na wyjaśnienia”; pytania „kwestionujące wiarę” są jej częścią i zarazem są nieodłączne od człowieczeństwa (Przekonać Pana Boga..., dz. cyt., s. 33, 10).

43 Por. słowa Tischnera: „Pan Bóg chce, byśmy szli do Niego z otwartymi oczyma. Właśnie w imię wiary chrześcijanin powinien uznać moc rozumu” (Przekonać Pana Boga..., dz. cyt., s. 24).

${ }_{44}$ Zob. J. Tischner, Myśli..., dz. cyt., s. 14.

45 Zob. J. Tischner, Ksiądz na manowcach, Kraków 2007, s.14.

${ }^{46}$ Przekonać Pana Boga..., dz. cyt., s. 24.

47 Por. słowa Tischnera: „Nie ma wiary bez spotkania ze słowem” (J. Tischner, Zrozumieć..., dz. cyt., s. 41); „Chrześcijaństwo jest [...] religią słowa, które ustanawia więź” (J. Tischner, Polski..., dz. cyt., s. 327).

${ }^{48}$ Zob. A. Michnik, J. Tischner, J. Żakowski, Między Panem..., dz. cyt., s. 554.

49 Zob. J. Tischner, Alfabet..., dz. cyt., s. 177.

5o Por. J. Tischner, Zrozumieć..., dz. cyt., s. 12.

${ }^{51}$ Por. słowa Tischnera: „[...] «więź» czyli religio: człowiek wybiera wierność Temu, kto najpierw jego wybrał” (J. Tischner, Ksiądz..., dz. cyt., s. 17). Por. także słowa Tischnera: „Wiara jest w istocie wiernością" (J. Tischner, Zrozumieć..., dz. cyt., s. 12).

${ }^{52} \mathrm{Na}$ gruncie humanistyki takie ujęcie relacji zachodzących między etyką i religią jest bowiem tylko jednym z możliwych. Por. J. Tischner, Idąc przez puste Błonia, Kraków 2005, s. 202, 225; 
wyraża się w pytaniu o czynnik wyjaśniający wzajemne oddziaływanie obu tych zjawisk. Wymóg tego wyjaśnienia czerpie swą moc z ich niesprowadzalnej do siebie natury: wyłaniająca się z myśli Tischnera etyka bazuje na fenomenie zobowiązania moralnego i zawiera się w stosunku do drugiego człowieka ${ }^{53}$, którego „twarz"54 stwarza to zobowiązanie; zaś ukazana w zapisie Kowalskiej i filozofii Tischnera religia zasadza się na fenomenie łaski i mieści się w relacji do Boga ${ }^{55}$, będącego źródłem łask, w tym podstawowej z nich - wiary ${ }^{56}$. Dane ze wstępnych analiz pozwalają rozważyć tezę, że wzajemne oddziaływanie etyki i religii jest możliwe przy założeniu pierwotnego względem nich czynnika metafizycznego ${ }^{57}$. Celem dalszych analiz będzie uzasadnienie tej tezy poprzez pokazanie, że etyczno-religijne miłosierdzie antropologiczne w rozumieniu Tischnera ma metafizyczne podstawy oraz istotę i że w pojęciach Tischnerowskiej metafizyki można określać zjawiska religijnego miłosierdzia antropologicznego ukazanego w zapisie Kowalskiej ${ }^{58}$. Cel ten będzie osiągany na drodze analizy porównawczej dwu, określonych w tytule artykułu, wizji miłosierdzia antropologicznego. Ich wybór pozwala rozważany w tezie czynnik metafizyczny rozpatrywać w jego dwojakim charakterze: mistycznym (s. Faustyna) i refleksyjnym (Tischner).

$\mathrm{Na}$ drodze zamierzonych analiz będzie można zdobyć podstawowe i pogłębione rozumienie miłosierdzia antropologicznego w obu jego badanych ujęciach. Wyniki analiz pozwolą także stwierdzić, czy wstępnie konstatowana ogólna wspólność w aspekcie religijnym miłosierdzia antropologicznego w obu tych ujęciach ma głębsze uzasadnienie; czy ta wspólność zachodzi

J. Kłoczowski, Mistyka a etyka, w: Fenomenologia polska a chrześcijaństwo, red. J. Gomułka, Kraków 2014, s. 241-257.

53 Zob. J. Tischner, Spór..., dz. cyt., s. 246.

${ }_{54}$ Zob. J. Tischner, Krótki..., dz. cyt., s. 30. Zagadnienie „twarzy” w rozumieniu Tischnera zostaje omówione w drugiej części studium, będącej osobnym artykułem.

${ }^{55} \mathrm{Z}$ tej relacji pochodzi też etyka religijna - por. słowa s. Faustyny: „[...] wszelki uczynek miłosierdzia wypływać będzie z miłości Bożej [...]” (Dz. 664); zob. J. Tischner, Idąc..., dz. cyt., S. 51 .

${ }^{6}$ Por. Dz. 1522; por. słowa Tischnera: „wiara jest łaską” (J. Tischner, Ksiądz..., dz. cyt., s. 21).

57 Por. T. Gadacz, Filozofia..., dz. cyt., s. 177.

${ }_{58}$ Por. słowa Tischnera o specyfice zapisu Kowalskiej ujmowanego w kontekście teologii mistrza Eckharta: „[...] Mistrz Eckhart jako teolog wiąże przeżycia «dialogiczne» miłości z ich fundamentem, czyli doświadczeniem dobra, natomiast siostra Faustyna do tej warstwy zagadnień już nie sięga, lecz najprościej w świecie zwierza się z tego, co bezpośrednio przeżywa” (J. Tischner, Drogi..., dz. cyt., s. 79). 
także w sferze podstaw i istoty miłosierdzia antropologicznego w obu jego badanych ujęciach?

Zaplanowane powyżej analizy będą prowadzone na płaszczyźnie (teo-)antropologii ujmowanej ontologicznie. Jej zastosowanie do badań miłosierdzia antropologicznego pozwoli uchwycić optymalną postać wzajemnego oddziaływania etyki i religii. Bowiem zgodnie ze wstępnymi ustaleniami w obu zestawianych wizjach miłosierdzie stanowi punkt kulminacyjny stawania się sobą człowieka. Zgodnie z wyborem płaszczyzny badawczej i tymi wstępnymi ustaleniami badane miłosierdzie będzie niniejszym rozpatrywane jako zjawisko (teo-)antropologii ujmowanej ontologicznie.

\section{Miłosierdzie antropologiczne w zapisie s. Faustyny - teo-antropologia w ujęciu ontologicznym}

Niniejsze analizy zapisu Kowalskiej dotyczą takiego miłosierdzia antropologicznego ${ }^{59}$, które jest momentem stawania się sobą człowieka okazującego to miłosierdzie. Analizy te są oparte na przeświadczeniu, że miłosierdzie antropologiczne jest kluczowym zjawiskiem w wyłaniającej się z Dzienniczka wizji człowieka. Przekonanie o powszechnym znaczeniu tego miłosierdzia ${ }^{60}$ może budzić wątpliwości w świetle słów Kowalskiej, w których jawi się ono jako jedna $\mathrm{z}$ wielu cnót, wyróżnionych przez nią tylko w oparciu o własne osobiste wybory religijne (Dz. 1242). Myśl o uniwersalnej wartości ukazanego w zapisie Kowalskiej badanego miłosierdzia pozwala podtrzymywać zawarta w nim wizja Boga ${ }^{61}$, wyznaczająca antropologię Dzienniczka z ideą upodabniania się do Boga jako jedną z naczelnych. W wizji tej wyróżnionymi co do rangi przymiotami Boga są ściśle ze sobą związane: miłość i miłosierdzie ${ }^{62}$. Forma tej więzi zostaje w Dzienniczku wyrażona w słowach: „Bóg jest miłością,

59 Cechy badanego miłosierdzia wyłaniamy z opisów o charakterze uniwersalnym (dotyczących „każdej duszy”, Dz. 283) - różnych od: opisów specyfiki życia zakonnego (zob. „życie doskonalsze”, Dz. 7) i opisów typów człowieka religijnego (por. „dusze wybrane”, Dz. 1601).

${ }^{60}$ Refleksję nad wymiarem uniwersalnym ukazanego w Dzienniczku miłosierdzia jako postawy człowieka zawierają analizy teologiczne przeprowadzone w: H. Wejman, Miłosierdzie jako istotny element duchowości chrześcijańskiej, Szczecin 1997.

${ }^{61} \mathrm{Na}$ temat wizji Boga w Dzienniczku zob. I. Werbiński, Bóg doświadczenia religijnego siostry Faustyny, w: Bóg i człowiek $w$ doświadczeniu religijnym, red. W. Słomka, Lublin 1986, s. 191-204.

${ }_{62}$ Por. słowa Kowalskiej: „I zrozumiałam, że największym przymiotem (Boga - L. M.) jest miłość i miłosierdzie” (Dz. 18o); por. także słowa z Dzienniczka: „[...] Miłosierdzie jest największym przymiotem Boga" (Dz. 301). 
a miłosierdzie jest Jego czynem, w miłości się poczyna, w miłosierdziu się przejawia” (Dz. 651) oraz „Miłość Boża kwiatem - a miłosierdzie owocem” (Dz. 949). W oparciu o ideę upodabniania się do Boga można wobec tego wstępnie sądzić, że miłosierdzie antropologiczne ${ }^{63}$ (por. Dz. 1336) wieńczy i wyraża miłość do drugiego człowieka ${ }^{64}$, w której zawiera się podobieństwo do Boga.

\section{Podstawy ontologiczne miłosierdzia antropologicznego w Dzienniczku}

Ukazane w Dzienniczku miłosierdzie antropologiczne będziemy rozpatrywać jako element zawartej w nim wizji człowieka, ujmowanego ontologicznie ${ }^{65}$. Wychodząc z przekonania, że ontologiczność człowieka z tej wizji najwyraźniej ujawnia się w zjawisku doskonalenia, najbliższe analizy poświęcimy wydobyciu jego generalnej struktury. Będziemy w nich zmierzać do pokazania w ostatniej części artykułu, że kulminację rozpatrywanego doskonalenia stanowi miłosierdzie antropologiczne.

W zapisie Kowalskiej wyróżniają się opisy doskonalenia człowieka religijnego (por. Dz. 749) - odnoszącego swą miłość do Boga jako celu (Dz. 373). Miłość do Boga jest odpowiedzią (Dz. 1365) na pierwotną (Dz. 231) względem niej miłość Bożą, udzielającą się w łaskach miłosierdzia (Dz. 1507). Przyjmując je, człowiek oddaje Bogu chwałę (Dz. 1629, por. Dz.1605). W Dzienniczku miłość do Boga określa pełnię człowieczeństwa (por. Dz. 201) - teo-antropologiczną doskonałość człowieka (Dz. 984). Polega ona na zjednoczeniu ${ }^{66}$ miłości

${ }^{63}$ Na temat więzi „cnoty miłosierdzia chrześcijańskiego” z miłością Bożą w kontekście naśladownictwa Boga zob. S. Smoleński, Cnota miłosierdzia chrześcijańskiego w życiu sługi Bożej siostry Faustyny, w: Posłannictwo..., dz. cyt., s. 23-30. Por. słowa badacza: „W jej (s. Faustyny L. M.) ujęciu Miłosierdzie Boże jest źródłem i zasadniczym fundamentem cnoty miłosierdzia, która znajduje w miłosierdziu Bożym swą przyczynę zarówno w wymiarze wzorczym, jak i sprawczym” (S. Smoleński, Cnota..., dz. cyt., s. 23).

${ }^{64}$ Por. słowa Kowalskiej: „[...] miłość czysta jest mi przewodniczką życia, a na zewnątrz miłosierdzie jest owocem jej" (Dz. 1363).

${ }_{65} \mathrm{~W}$ ten sposób ujmowany człowiek z zapisu Kowalskiej ujawnia się w perspektywie możliwości i powinności dążenia do doskonałości religijnej (por. Dz. 1488).

${ }^{66}$ Chodzi o zjednoczenie dostępne człowiekowi za życia ziemskiego i różne od zjednoczenia „wiecznego i całkowitego” (Dz. 160o). Na temat sensów i rodzajów zjednoczenia z Bogiem występujących w Dzienniczku w kontekście życia mistycznego s. Faustyny zob. O. Filek, Droga sługi Bożej siostry Marii Faustyny do zjednoczenia z Bogiem, w: Posłannictwo..., dz. cyt., zwł. s. 47-56, $70,76-78$. 
do Boga z miłością Bożą (Dz. 457) ${ }^{67}$ i oznacza „świętość osobistą" ${ }^{68}$ (Dz. 1363). Zjednoczenie z Bogiem zachodzi poprzez łaski Boże (Dz. 1750), pochodzące $\mathrm{z}$ miłosierdzia Bożego ${ }^{69}$. Zjednoczenie to wymaga od człowieka spełnienia pewnych warunków, bowiem w punkcie wyjścia ukierunkowana na Boga: „Miłość duszy nie jest [...] taka, jak Bóg tego żąda” (Dz. 96). W świetle tych słów, wybierając Boga jako swój cel, człowiek z zapisu Kowalskiej staje wobec wymogu ontologicznego stania się sobą. By miłość ludzka mogła „dosięgnąc" (Dz. 450) Boga, musi udoskonalić się (Dz. 231) w swych odniesieniach stanowiących o człowieczeństwie człowieka. W świetle zapisu Kowalskiej wzorem doskonałości ludzkiej jest osoba Chrystusa (Dz. 1333). Formą doskonalenia miłości ludzkiej jest naśladowanie Go (Dz. 1505) w celu upodobnienia się do Niego (Dz. 1336). Kulminacja tego podobieństwa to zarazem optimum teo-antropologicznego bycia sobą (Dz. 604) ukazanego w Dzienniczku człowieka.

Najbliższe analizy Dzienniczka będą podporządkowane pytaniu: jaka musi być miłość ludzka (bycie sobą), by mogła jednoczyć się z miłością Bożą (pełnia bycia sobą)? Poszukiwania odpowiedzi na to pytanie obejmą najpierw określenie podstaw doskonalenia miłości ludzkiej, a następnie - jego poszczególnych wymiarów.

Podstawy oraz cechy główne omawianego doskonalenia można określić na drodze analiz stosunku człowieka do pochodzących z miłosierdzia Bożego łask. Cechą podstawową i stałą odniesienia do nich jest modlitwa (nieustanna) (Dz. 325). Poprzez nią ,wszelka łaska spływa” (Dz. 146). Pierwszym znaczącym ontologalnie działaniem laski jest „rozbudzenie” (Dz. 1435) w człowieku cnót teologalnych (Dz. 1435) i skruchy ${ }^{7^{\circ}}$ (Dz. 1435). Podtrzymanie doświadczenia tego zbawczego działania łaski stanowi o kolejnym wyznaczniku podstawowej relacji do łaski Bożej. Określa go „wzbudzanie w sobie aktów teologalnych" (Dz. 1813). Cnoty teologalne leżą, wespół z modlitwą, u podstaw bycia sobą człowieka religijnego. Cnoty te umożliwiają właściwe przyjmowanie łask Bożych (por. Dz. 186). Określenie głównych sposobów tego przyjmowania

${ }^{67}$ Por. słowa Kowalskiej: „Ogień mojej miłości, stworzony, został złączony z żarem wiekuistej miłości Jego. Wszystkie łaski ta jedna przewyższa swym ogromem” (Dz. 1056).

${ }^{68}$ O drodze do świętości jako „wysiłkach w cnocie” w ramach naśladowania Chrystusa zob. Dz. 1505 .

${ }^{69}$ Por. słowa Kowalskiej: „Wszelka łaska wypływa z miłosierdzia [...]” (Dz. 1507) oraz „Wszystko się zaczyna z miłosierdzia Twego i na miłosierdziu Twoim się kończy...” (Dz. 1506).

${ }^{70} \mathrm{Na}$ temat zagadnienia skruchy w wizjach Kowalskiej zob. M. Kocik, Miłosierdzie wobec choroby i śmierci duchowej według św. siostry Faustyny, w: Współczesne oblicza miłosierdzia, red. L. Mateja, Kraków 2007, s. 99. 
poszerzy opisy badanych podstaw teo-antropologicznych i dostarczy kryteriów do odsłonięcia wymiarów bycia sobą człowieka religijnego z zapisu Kowalskiej. Dzienniczek pozwala kryteria te uzasadniać antropologicznie - zakorzeniać je w wyróżnionych w nim władzach duchowych, jak zobaczymy: woli, rozumie i sercu (por. Dz. 392).

U początków ukazanego w Dzienniczku doskonalenia teo-antropologicznego leży „wzbudzanie” (por. Dz. 225) skruchy, „rozbudzonej” (Dz. 1435) w człowieku przez łaskę. Skrucha religijna „przemienia serca” (Dz. 388), prowadzi do nawrócenia (Dz. 1577). W nawróceniu tym i całym przebiegu doskonalenia wymogi miłości Bożej są przedkładane nad pragnienia i potrzeby natury ludzkiej (Dz. 1549) oraz „miłości własnej” (Dz. 210) - źródła antropologicznych przeszkód doskonałości religijnej (Dz. 1488). Rezultatem nawrócenia jest „Wolność ducha”11 (Dz. 1331) - podstawowy wyznacznik teo-antropologicznego bycia sobą.

Pierwszy wymiar ukazanego w zapisie Kowalskiej doskonalenia teo-antropologicznego ujawnia się w odniesieniu do łaski jako mocy Bożej, pochodzącej od Boga jako „Pana Najwyższego” (Dz. 283). Przyjęcie tej łaski polega na poddaniu się działaniu (Dz. 1326) Wszechmocy Bożej (Dz. 142) ${ }^{72}$. Posłuszeństwo łasce domaga się od człowieka „zaparcia się samego siebie” (Dz. 462). Człowiek wyrzeka się w nim zadzierzgniętych mocą miłości własnej więzi z rzeczywistością jako wielością stworzenia Bożego (Dz. 1331). W wyrzeczeniu się tym wyzwala się w człowieku moc duchowa ${ }^{73}$, jego ludzka miłość rośnie w siłę i uwzniośla się (por. Dz. 1246) ${ }^{74}$. Czerpiąc z tej mocy, człowiek „panuje nad sobą” (Dz. 1825, por. Dz. 234) i porządkuje swe relacje ze stworzeniem (por. Dz. 373, 1331). Posłuszeństwo łasce zakłada w człowieku sferę wielości pewnych mocy - w tym woli jako mocy duchowej (por. Dz. 495) - zróżnicowanych hierarchicznie. W sferze tej moc wyższa panuje nad niższą (por. Dz. 138).

Kolejny wymiar rozpatrywanego doskonalenia odsłania się w relacji do niosącej „oświecenie umysłu” (Dz. 410) łaski jako światła prawdy Bożej (Dz. 376), pochodzącego od Boga - „Ducha czystego” (Dz. 135). Przyjęcie tej łaski polega

${ }^{71}$ Por. słowa Kowalskiej: „Miłość Boża czyni duszę swobodną” (Dz. 890).

${ }^{72}$ Por. słowa s. Faustyny: „Niech żadna dusza nie wątpi, chociażby była najnędzniejsza, póki żyje - każda może się stać wielką świętą, bo wielka jest moc łaski Bożej. Od nas zależy tylko nie stawiać oporu Działaniu Bożemu” (Dz. 283).

73 Por. słowa Kowalskiej: „[...] [z posłuszeństwem] wstępuje moc w duszę” (Dz. 1685).

74 O wywyższeniu duchowym: warunkowanym posłuszeństwem Bogu i pochodzącym od Jego wszechmocy zob. Dz. 1732. 
na wierności wobec niej (Dz. 1599). Wierność ta wymaga od człowieka zgodności z samym sobą. Kształtuje się ona w procesie „badania samego siebie” (Dz. 337), poznawania prawdy o sobie ${ }^{75}$ (Dz. 112). Zgodność z łaską zakłada wobec tego w człowieku sferę samo odniesienia (refleksyjność). Prawda, odsłaniająca się człowiekowi w samopoznaniu teo-antropologicznym, ujawnia mu jego skończoność i zarazem wielkość (Dz. 1336). Skończoność ta określa podstawy skruchy religijnej, które zapis Kowalskiej nazywa wymownie: „nędzą” (Dz. 56), symptomatycznie wyrażającą się w miłości własnej; zaś „wielkość” (Dz. 889) - daje podstawę do wdzięczności religijnej (por. Dz. 1362) odnoszonej do łask. Wedle podstawowej z nich człowiek to obraz Boga, który jest Miłością (Dz. 589). W religijnym samo-poznaniu miłość ludzka zyskuje wolność od (auto) iluzji (por. Dz. 140).

Ostatni wymiar ukazanego w Dzienniczku doskonalenia wyłania się w stosunku do łaski osobowej obecności Boga, która rozpala serce (por. Dz. 2). Łaska ta pochodzi z samej istoty miłosiernej miłości Bożej (por. Dz. 822), w której Bóg „zniża się” (Dz. 1489) ku stworzeniu - udziela się w sposób ofiarny (por. Dz. 1103). Przyjęcie tej łaski realizuje się w ufności ${ }^{76}$ wobec niej (Dz. 1364). Ufność ta wymaga od człowieka „oddania się Bogu” (Dz. 1748): ofiarowania Mu tego, co istotnie człowiecze i „zdania się” (Dz. 589) na Niego w Jego łaskach. Wedle zapisu Kowalskiej „wyłączna własność” (Dz. 1318) człowieka to jego „nędza” (Dz. 1318); zaś Bóg i Jego główna łaska w człowieku jako obrazie Bożym to miłość, której „Jądro [...] - ofiara i cierpienie"77 (Dz. 1103). By zdać się na Boga, człowiek musi wobec tego przełamać lęk przed zatraceniem się w cierpieniu ofiarnym (Dz. 589). Lęk ten jest usuwany przez miłość (Dz. 589). Ufność łasce wymaga wobec tego od człowieka miłości. Ona zaś im bardziej jest ofiarna ${ }^{78}$, tym bardziej staje się sobą - „królową” (Dz. 201) wolną od wszelkiego zniewalającego lęku (por. Dz. 890) ) $^{79}$ W myśl zapisu Kowalskiej ofiar-

75 O pokorze jako prawdzie o sobie zob. Dz. 1502.

${ }^{76}$ Na temat ufności w Dzienniczku zob. P. Kreis, Cnota ufności w pismach sługi Bożej siostry Faustyny, w: Posłannictwo..., dz. cyt., s. 31-46.

77 Teologiczna analiza zagadnienia cierpienia w doświadczeniu Kowalskiej zob. W. Nowacki, Zbawcza wartość cierpienia $w$ doświadczeniu świętej Faustyny Kowalskiej, w: Dogmatyka w perspektywie Bożego miłosierdzia, red. K. Góźdź, K. Guzowski, Lublin 2010, s. 385-399; na temat stosunku s. Faustyny do cierpienia zob. I. Borkiewicz, Stosunek służebnicy Bożej siostry Faustyny do cierpienia, w: Posłannictwo..., dz. cyt., s. 113-139.

${ }^{78}$ Por. słowa Kowalskiej: „[...] miłość mierzy się miarą ofiary i cierpień” (Listy siostry Faustyny, oprac. B. Piekut, Kraków 2005, s. 150).

79 Por. słowa s. Faustyny: „Zaufałam Bogu i nie lękam się niczego” (Dz. 589). 
ność miłości spełnia się: dla Boga ${ }^{80}$ i za bliźniego - postrzeganego w wierze (Dz. 1522) jako obraz Boży ${ }^{81}$. Ufność wobec łaski zakłada więc w człowieku religijnym z zapisu Kowalskiej sferę odniesienia do Boga (religia) i do drugiego człowieka (etyka religijna).

Powyższe analizy Dzienniczka pozwalają sądzić, że cechami miłości ludzkiej uzdolniającymi ją do zjednoczenia się z miłością Bożą (pełnia bycia sobą) jest ofiarność (por. Dz. 1735) i jej warunki: uwznioślona (por. Dz. 593) moc (por. Dz. 1685) duchowego panowania nad sobą (Dz. 582) i „Czystość” (Dz. 582) samopoznania. Jedność tych cech stanowi o teo-antropologicznym byciu sobą człowieka z zapisu Kowalskiej.

Dzienniczek pozwala etyczny aspekt religijnej miłości ofiarnej uznawać za najwyższy stopień jej doskonałości. Przekonanie to można wspierać na wyrażonym w Dzienniczku sposobie rozumienia upodabniania się do Boga. Wyróżniony w zapisie Kowalskiej aspekt tego upodobnienia ma za wzór miłość Bożą w miłosierdziu (Dz. 1242). W tym kontekście zostaje także wyróżniony "Jezu na krzyżu rozpięty" (por. Dz. 1333) i Jego miłosierne serce (Dz. 660) - jako wzór do naśladowania (Dz. 1333). W procesie upodabniania się do Chrystusa zostaje uwydatniony w zapisie Kowalskiej wymiar mistyczny, który znajduje swój wyraz w śmiałych metaforach: pragnienia „wchłonięcia Boga w siebie” (Dz. 193), „przemienienia się w miłosierdzie” Boże (Dz. 163). Okoliczność dla nas znacząca w zawartym w Dzienniczku opisie rozpatrywanego upodabniania się dotyczy jego kulminacji. Zachodzi ona w relacji do bliźnich. Człowiek religijny z zapisu Kowalskiej po to pragnie „wchłonąć Boga w siebie, aby Go oddać duszom” (Dz. 193); po to, chce "przesiąknąć miłosierdziem Bożym (Dz. 167), by je wydać bliźnim (Dz. 392). Wyjaśnienie dla religijnego zapośredniczenia etycznego zwrotu ku bliźnim pochodzi z samopoznania teo-antropologicznego (Dz. 56): „bez Jezusa nie zbliżyłabym się do innych, bo wiem, czym jestem sama z siebie" (Dz. 193).

${ }^{80}$ Por. słowa Kowalskiej: „tylko Bóg sam jest godzien jej (duszy wolnej - L. M.) miłości” (Dz. 890).

${ }^{81}$ Por. słowa s. Faustyny: „Wszystkich ludzi kocham dlatego, bo widzę w nich obraz Boży” (Dz. 373). 


\section{Miłosierdzie antropologiczne} jako kulminacja doskonalenia religijnego

Przeprowadzone powyżej analizy zostaną w ostatniej części niniejszego artykułu wykorzystane do wykazania, że kulminacją ukazanego w Dzienniczku stawania się sobą jest miłosierdzie antropologiczne. Analizy te pozwalają osiągać określony w ten sposób cel poprzez pokazanie, że optymalna postać badanego miłosierdzia jest kulminacją teo-antropologicznej ofiarności religijnej i zarazem stanowi optimum podobieństwa do Boga.

Jak w Dzienniczku wygląda kulminacja teo-antropologicznej ofiarności? W świetle tego zapisu kryterium wielkości ofiary podjętej przez człowieka religijnego jest wielkość oddanego dobra i przyjętego cierpienia. W odniesieniu do człowieka religijnego największym dobrem jest „obcowanie z Bogiem” (Dz. 309) w łaskach miłosierdzia; największe cierpienie teo-antropologiczne oznacza rozpacz człowieka nieczerpiącego ze „zdroju miłosierdzia”, lecz zdanego tylko na konsekwencje swej „miłości własnej”. Na podstawie zapisu Kowalskiej można sądzić, że optimum teo-antropologicznej ofiarności zachodzi w strukturze relacji między, z jednej strony, człowiekiem miłującym Boga, aż po „zażyłe” (Dz. 95) obcowanie z Nim, a z drugiej strony - grzesznikami w rozpaczy - bez ufności w miłosierdzie Boże (Dz. 308). W myśl tego zapisu kulminacja teo-antropologicznej ofiarności polega na oddaniu takim właśnie grzesznikom wszelkich „pociech w duszy, które płyną z obcowania z Bogiem” (Dz. 309) i przyjęciu cierpienia, płynącego z tej rozpaczy (por. Dz. 309). Sensem tej ofiary jest „wynagrodzenie Bogu za dusze, które nie dowierzają dobroci” (Dz. 309) Bożej i uproszenie łaski przebaczenia dla nich. Właściwie teo-antropologiczną formą tej ofiary jest modlitwa. Wznoszona ku Bogu ofiara o takich cechach oznacza wstawiennictwo (por. Dz. 202).

Jak w Dzienniczku wygląda największe podobieństwo do Boga? Określenie tego podobieństwa zawiera się w słowach: „Wtenczas jesteśmy najwięcej podobni do Boga, kiedy przebaczamy bliźnim. Bóg jest miłością, dobrocią i miłosierdziem” (Dz. 1148). Pozostaje nam teraz pokazać, że optymalną postacią odnoszonego do bliźniego miłosierdzia-przebaczenia jest wstawiennictwo.

W myśl zapisu Kowalskiej przebaczenie ludzkie sięga swego apogeum wówczas, gdy jest dokonane „po Bożemu” (Dz. 1745) - na wzór przebaczenia Bożego. W przebaczeniu „po Bożemu” winowajca otrzymuje nie tylko odpuszczenie winy, ale też łaski Boże (Dz. 1745). Akt dopełniający miłosierdzie-przebaczenie, odniesiony do bliźniego, musi wobec tego w jakiś sposób pociągać za sobą łaski dla niego. Na ten akt naprowadzają pełne znamiennej dla mistyka śmiałości 
słowa Kowalskiej, w których pisze o „zmuszaniu Boga do udzielenia łaski” (por. Dz. 202) drugiemu człowiekowi. W świetle tych słów taką szczególną „moc nad Bogiem" (Dz. 202) ma oparta na ufności (Dz. 453) ofiara wstawiennicza w formie modlitwy (Dz. 202). Zapis Kowalskiej pozwala także wskazywać optimum takiej „,wymuszonej” na Bogu łaski dla grzesznika w rozpaczy i bez ufności w miłosierdzie Boże (Dz. 308). Optymalne wstawiennictwo uprasza dla takiego grzesznika „Boże miłosierdzie-przebaczenie”, które nie tyko odpuszcza winę, ale i daje mu łaskę dla niego najważniejszą: odzyskanej ufności w miłosierdzie Boże.

\section{ABSTRAKT}

Artykuł stanowi pierwszą część studium poświęconego analizie porównawczej dwu wizji miłosierdzia antropologicznego: religijnej o charakterze mistycznym - ukazanej w Dzienniczku Faustyny Kowalskiej i etyczno-religijnej o charakterze refleksyjnym - zawartej w myśli filozoficznej Józefa Tischnera. Niniejszy artykuł koncentruje się na analizie wizji miłosierdzia antropologicznego ukazanej w Dzienniczku. Ogólna zgodność badanych wizji w aspekcie religijnym pozwala badać je z perspektywy jednego problemu: wzajemnego oddziaływania etyki i religii. Problem jest podejmowany na gruncie (teo-)antropologii ontologicznej (bada człowieka od strony możliwości i powinności bycia sobą). Cel analiz to uzasadnienie tezy, iż wzajemne oddziaływanie etyki i religii jest możliwe przy założeniu czynnika metafizycznego. Cel ten osiąga się poprzez pokazanie, iż etyczno-religijne miłosierdzie antropologiczne w rozumieniu Tischnera ma metafizyczne podstawy oraz istotę i że w pojęciach Tischnerowskiej metafizyki można określać zjawiska religijnego miłosierdzia antropologicznego ukazanego w Dzienniczku.

\section{SŁOWA KLUCZOWE}

miłosierdzie antropologiczne, etyka, religia, metafizyka, bycie sobą, (teo-)antropologia ontologiczna

\section{Abstract}

The anthropological mercy in the mystical experience (Faustina Kowalska) and the philosophical reflection (Joseph Tischner). The items of the ontological (theo-) anthropology. Part I

The article is the first part of the study in the scope of contains a comparative analysis of the two concepts of anthropological mercy: the religious, in the mystical sense, 
concept of Faustina Kowalska (Diary) and the ethical-religious, in the reflective sense, concept of Joseph Tischner. This article concerns the anthropological mercy in the approach of Kowalska. The general similarities between this two concepts in religious dimension allow us to consider them from the perspective of one problem: the interaction between the ethics and the religion. The problem is studied on the basis of ontological (theo-)anthropology (a person is researched from the perspectives of the possibility and obligation of being self). The purpose of the analysis is a justification for the thesis that the interaction between the ethics and the religion is based on metaphysical factor. This purpose is achieved by demonstrating that the ethical-religious anthropological mercy in the philosophical approach of Tischner have a metaphysical basis and essence - and that in this metaphysical terms can be explained the phenomena of the religious anthropological mercy in the Diary.

\section{KeYWORDS}

anthropological mercy, ethics, religion, metaphysics, being oneself, ontological (theo-) anthropology

\section{BIBLIOGRAFIA}

Borkiewicz I., Stosunek służebnicy Bożej siostry Faustyny do cierpienia, w: Posłannictwo siostry Faustyny, red. C. Drążek, Kraków 1991, s. 113-139.

Filek O., Droga sługi Bożej siostry Marii Faustyny do zjednoczenia z Bogiem, w: Posłannictwo siostry Faustyny, red. C. Drążek, Kraków 1991, s. 47-78.

Gadacz T., Bóg w filozofii Tischnera, „Znak” 2001 nr 550, s. 25-38.

Gadacz T., Chrześcijańskie korzenie Tischnerowskiej filozofii człowieka, „Znak” 2004 nr 588, s. $77-87$.

Gadacz T., Filozofia Boga w xx wieku. Od Lavelle’a do Tischnera, Kraków 2007.

Grygiel L., Zawierzyć Bożemu miłosierdziu. Mistyka siostry Faustyny, Kraków 2000. Kłoczowski J., Mistyka a etyka, w: Fenomenologia polska a chrześcijaństwo, red. J. Gomułka, Kraków 2014, s. 241-257.

Kocik M., Miłosierdzie wobec choroby i śmierci duchowej według św. siostry Faustyny, w: Współczesne oblicza miłosierdzia, red. L. Mateja, Kraków 2007, s. 87-108.

Kowalska F., Dzienniczek. Miłosierdzie Boże w duszy mojej, Warszawa 2005.

Kreis P., Cnota ufności w pismach sługi Bożej siostry Faustyny, w: Posłannictwo siostry Faustyny, red. C. Drążek, Kraków 1991, s. 31-46.

Listy siostry Faustyny, oprac. B. Piekut, Kraków 2005.

Machniak J., Doświadczenie Boga w Tajemnicy Jego Miłosierdzia u Bł. Siostry Faustyny Kowalskiej. Studium krytyczne w świetle myśli teologicznej, Kraków 1999. 
Machniak J., Chcę żyć miłością. Życie mistyczne św. siostry Faustyny Kowalskiej, Kraków 2002.

Michnik A., Tischner J., Żakowski J., Między Panem a Plebanem, Kraków 1995.

Nowacki W., Zbawcza wartość cierpienia w doświadczeniu świętej Faustyny Kowalskiej, w: Dogmatyka w perspektywie Bożego miłosierdzia, red. K. Góźdź, K. Guzowski, Lublin 2010, s. 385-399.

Przekonać Pana Boga. Z ks. Józefem Tischnerem rozmawiają Dorota Zańko i Jarosław Gowin, Kraków 2010.

Smoleński S., Cnota miłosierdzia chrześcijańskiego w życiu sługi Bożej siostry Faustyny, w: Posłannictwo siostry Faustyny, red. C. Drążek, Kraków 1991, s. 23-30.

Tischner J., Alfabet duszy i ciała, Kraków 2018.

Tischner J., Drogi i bezdroża miłosierdzia, Kraków 2015.

Tischner J., Etyka wartości i nadziei, w: D. von Hildebrand, J. Kłoczowski, J. Paściak, J. Tischner, Wobec wartości, Poznań 1984, s. 55-149.

Tischner J., Filozofia dramatu. Wprowadzenie, Paris 1990.

Tischner J., Idac przez puste Błonia, Kraków 2005.

Tischner J., Ksiądz na manowcach, Kraków 2007.

Tischner J., Myślenie według wartości, Kraków 1982.

Tischner J., Myślenie w żywiole piękna, Kraków 2005.

Tischner J., Spór o istnienie człowieka, Kraków 1998.

Tischner J., Sprawa osoby - wstępne przybliżenie, „Logos i Ethos” 1992 nr 2, s. 5-19.

Tischner J., Zrozumieć własną wiarę, Kraków 2006.

Tischner J., Żakowski J., Tischner czyta „Katechizm”, Kraków 2009.

Urbański S., Miłosierdzie droga do świętości według św. Faustyny, „Veritati et caritati” 5 (2015), s. 101-117.

Wejman H., Miłosierdzie jako istotny element duchowości chrześcijańskiej. Studium z teologii życia wewnętrznego, Szczecin 1997.

Werbiński I., Bóg doświadczenia religijnego siostry Faustyny, w: Bóg i człowiek w doświadczeniu religijnym, red. W. Słomka, Lublin 1986, s. 191-204.

Werbiński I., Idea miłosierdzia jako rys duchowej postawy chrześcijańskiej w ujęciu siostry Faustyny, w: Miłosierdzie w postawie ludzkiej, red. W. Słomka, Lublin 1989, s. $185-197$.

Wider D., Mistyka sługi Bożej siostry Faustyny, w: Posłannictwo siostry Faustyny, red. C. Drążek, Kraków 1991, s. 79-94. 